\title{
Tip 4 Kurulum ile Betonarme Boru Tasarımı
}

\author{
Havvanur KILIÇ ${ }^{1}$ \\ Onur DEMÍRC $\dot{I}^{2}$
}

\section{$\ddot{O Z Z}$}

Gömülü betonarme boru tasarımında yaygın olarak kullanılan yöntemlerden birisi ACPA tarafından 1970'li yıllarda geliştirilmeye başlanılan doğrudan tasarım yöntemidir. Bu yöntemde (SIDD) Tip 4 boru kurulumunda tabanda kayaç malzeme olmadiğında boru tabanında özel bir yatak malzemesine ihtiyaç yoktur ve gömülme için herhangi bir kontrol gerektirmemektedir. Bu çalışmada, doğrudan tasarım yöntemine göre Tip 4 kurulum ile gömülen bir betonarme borunun davranışı incelenmiştir. $\mathrm{Bu}$ kapsamda zemin-yapı etkileşimi dikkate alınarak beton bir borunun tasarımı için parametrik sayısal analizler yapılmıştır. Analizlerde gömme derinliği ve boru çapı değişimi dikkate alınarak hesaplanan kesit tesirlerine göre gerekli donatı alanları belirlenerek Tip 4 kurulum koşulları için bir abak oluşturulmuştur. Ayrıca belirlenen bu donatı alanları, ülkemizde gömülü boruların tasarımında yaygın olarak kullanılan İller Bankası A.Ş'nin kullandığı donatı alanları ile karşılaştırılmıştır. Böylece Tip 4 kurulum koşulları için bu abaktan yararlanılarak pratik olarak tasarım yapılabilmesi amaçlanmıştır.

Anahtar Kelimeler: Gömülü betonarme borular, sonlu elemanlar analizi, doğrudan tasarım.

\section{ABSTRACT \\ Design of Buried Reinforced Concrete Pipes with SIDD Type IV Installation}

One of the most common and widely used methods of buried reinforced concrete pipe design is the direct design method (SIDD) which was started being developed in 1970's. In SIDD Type IV pipe installation, there is no need to use a special bedding material under the pipe invert because a rock material is used in foundation soil. In this study, the behavior of the buried reinforced concrete pipe with SIDD Type IV installation is investigated. In this scope, a parametric investigation was conducted with numerical analysis to design a concrete pipe considering soil-structure interaction concept. In numerical analysis, the

\footnotetext{
Not: Bu yazı

- Yayın Kurulu’na 28 Kasım 2020 günü ulaşmıştır. 8 Mayıs 2021 günü yayımlanmak üzere kabul edilmiştir.

- 31 Temmuz 2022 gününe kadar tartışmaya açıktır.

- https://doi.org/10.18400/tekderg.832738

1 Yıldız Teknik Üniversitesi, İnşaat Mühendisliği Bölümü, İstanbul - kilic@yildiz.edu.trhttps://orcid.org/0000-0001-9455-1687

2 Yıldız Teknik Üniversitesi, İnşaat Mühendisliği Bölümü, İstanbul - onurdemirci1094@gmail.com https://orcid.org/0000-0002-3385-3056
} 
effects of varying design parameters are investigated such as properties like burial depths and diameter of pipes. Therefore, a reinforcement area chart has been created according to the SIDD Type IV design calculation results which includes internal forces obtained from pipe cross section. Furthermore, these obtained reinforcement areas are compared with reinforcement areas used by Iller Bankası A.Ş which are widely used in our country for buried pipe design. Hence, the main scope is to design concrete pipes practically by using this chart for SIDD Type IV conditions.

Keywords: Buried reinforced concrete pipes, finite element analysis, direct design.

\section{GİRiș}

Gömülü boruların üzerine etkiyen yüklerin hesabı ve boru hatlarının güvenli tasarımı için 1900'lerden günümüze kadar çalışmalar halen sürdürülmektedir. Düşey yükler altında şekil değişimine uğramayan veya çok küçük şekil değişimlerine uğrayan borular rijit boru olarak adlandırılmakta ve üzerine etkiyen düşey yükleri boru tacından boru tabanında yatak düzeyine aktararak taşımaktadırlar. Deneysel çalışmalar gömülü rijit borular üzerine etkiyen prizma yükünün mevcut zemin yükünden daha fazla olduğunu göstermektedir.

Dolgu Yüzeyi

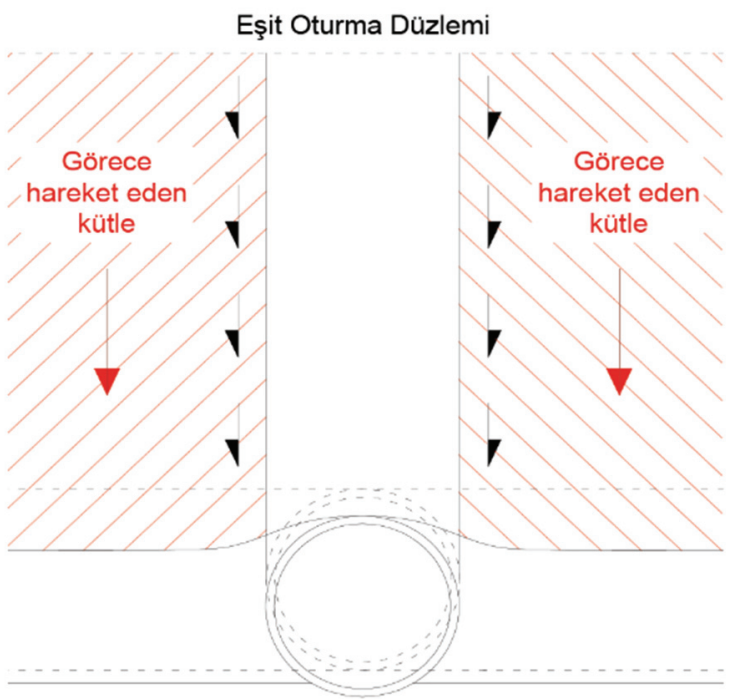

Şekil 1 - Gömülü beton boru-zemin etkileşimi [7]

Marston ve Anderson (1913) hendek ortamına yerleştirilmiş rijit bir borunun taç düzeyine etkiyen düşey gerilme hesabında, Janssen (1895)' in Silo Teorisi'ni temel almıştır [1, 2]. Bu hesaplarda, boru üzerindeki zemin prizması ağırlı̆̆ı ve ilave hareketli yük ile hendek yan duvarları ile geri dolgu arasındaki sürtünme de dikkate alınmaktadır [3, 4]. Genellikle boru 
rijitliği ile gömülü bulunduğu zemin ortamının rijitliği birbirinden farklı olduğundan, borunun üzerinde yer alan zemin prizması ile komşu zemin prizmaları arasında bir görece hareket söz konusudur. Bu hareketin yönü ve büyüklüğü boru üzerine etkiyen zemin gerilmelerinin büyüklüğünü etkilemektedir. Rijit (betonarme) borularda boru çevresinde yer alan geri dolgu boruya göre daha fazla sıkışacağından, boru üzerindeki zemin prizması ile yan zemin prizmaları ara yüzeylerinde aşağı yönlü kayma kuvvetleri gelişir (Şekil 1). Görece hareketin büyüklüğüne bağlı olarak yan zemin prizması nedeniyle oluşan gerilmeler rijit boru üzerine aktarılır [5]. Bu nedenle rijit boruların tasarımında gömülme koşullarına bağlı olarak boruya aktarılacak gerilmelerin gerçekçi olarak tahmini önemlidir [6].

Boruların tasarımında genellikle yarı-ampirik yaklaşımlara dayanan yöntemlerden, arazi ve laboratuvar deneyleri ve sayısal analizlerden yararlanılabilir. Gömülü boru ve boruyu çevreleyen zeminin davranışı zemin-yapı etkileşimi problemi olarak ele alındığından boruların davranışı yükleme miktarı, boru rijitliği, yataklama, geri dolgu özellikleri ve yerel zemin koşullarından etkilenmektedir [7].

Gömülü boru hatlarında amaçlanan yapısal performansın elde edilebilmesi için yönetmeliklere uygun bir yataklama ve geri dolgu uygulaması gereklidir. Yatak ve dolgu malzeme özellikleri temel zemini koşullarına, boru cinsine, kullanım amacına ve boru üzerine etkiyen statik ve dinamik yüklere vb. birçok faktöre göre değişebilir. Genellikle su, atık su ve drenaj borusu uygulamalarında Amerikan Su İşleri Birliği (AWWA) tasarım kılavuzlarına ve standartlarına, ASTM ve AASHTO'nun yürürlükteki standartlarına uyulmaktadır. Ayrıca beton borular için doğrudan tasarım yöntemi (ASCE 15-98) veya bazı üretici firmaların geliştirdiği özel tasarım kılavuzları dikkate alınmaktadır [8]. Bu tasarım kılavuzlarında yataklama ve dolgu malzemeleri için açıklamalar ve sınıflandırmalar yer almakta, böylece tasarımın öngörülen servis süresi boyunca sorunsuz işlev görebilmesi için yeterli dayanıma ve/veya rijitliğe ve duraylılığa sahip olması sağlanabilmektedir. Gömülü beton boruların tasarımında genellikle doğrudan ve dolaylı tasarım yöntemi olarak bilinen yöntemler kullanılır. Bu yöntemlerin detayları ve avantaj-dezavantajları Erdoğmuş vd. (2009)'da ayrıntılı bir şekilde sunulmuştur [9]. Allard ve Naggar (2016)'da doğrudan tasarım yönteminde kullanılan Heger basınç dağılımının zemin-yapı etkileşimi kapsamında doğruluğu ve uygulanabilirliğini parametrik sayısal analizler ile araştırılmıştır [10].

Beton boruların kurulumu AASHTO LRFD (2014) Köprü Tasarım Şartnamesi, Bölüm 27 veya ASCE 15-98'e uygun olarak gerçekleştirilir. Şekil 2'de hendek veya dolgu durumunda boru gömülmesi ve boru gömülme terminolojisi gösterilmiştir. Burada $\mathrm{D}_{\mathrm{o}}$ boru diş çap1, $\mathrm{D}_{\mathrm{i}}$ boru iç çap1, H boru tacından zemin yüzüne olan dolgu yüksekliğini göstermektedir. Boru tabanında boru çapının 1/3D $\mathrm{D}_{\mathrm{o}}$ kadarlık bölümü (orta yatak) olarak ifade edilerek genellikle gevşek bırakılmaktadır.

ASTM C76'da dolaylı tasarım yöntemi ve ASCE 15-98 standardına göre ise doğrudan tasarım için standart kurulumlar (SIDD) kullanılarak tasarlanan gömülü beton boru hatlarının kurulum uygulamaları belirtilmiştir. Bu standart dolgu malzemeleri için I, II ve III, IV kategorilerinde farklı zeminler tanımlanmıştır (Tablo 1). Bunlardan I ve II kategorileri iri daneli zeminleri ve III ve IV kategorileri ince daneli zeminleri temsil etmektedir. Standartta borunun oturduğu yatak, boru yan bölgesi ve üst dolgu olarak üç farklı dolgu bölgesi tanımlanmıştır. Tablo 1'de doğrudan tasarım yönteminde dolgu malzemesi olarak kullanılacak zeminlerin USCS ve AASHTO zemin sinıflandırma sistemlerine göre karşılıkları belirtilmiştir. Doğrudan tasarım (SIDD) Tip 4 kurulum 
uygulamasında, boru tabanında kaya olmadığı durumda yatak tabakası düzenlenmeden kötü derecelenmiş temel zemini üzerine beton boru yerleştirilebilmektedir.

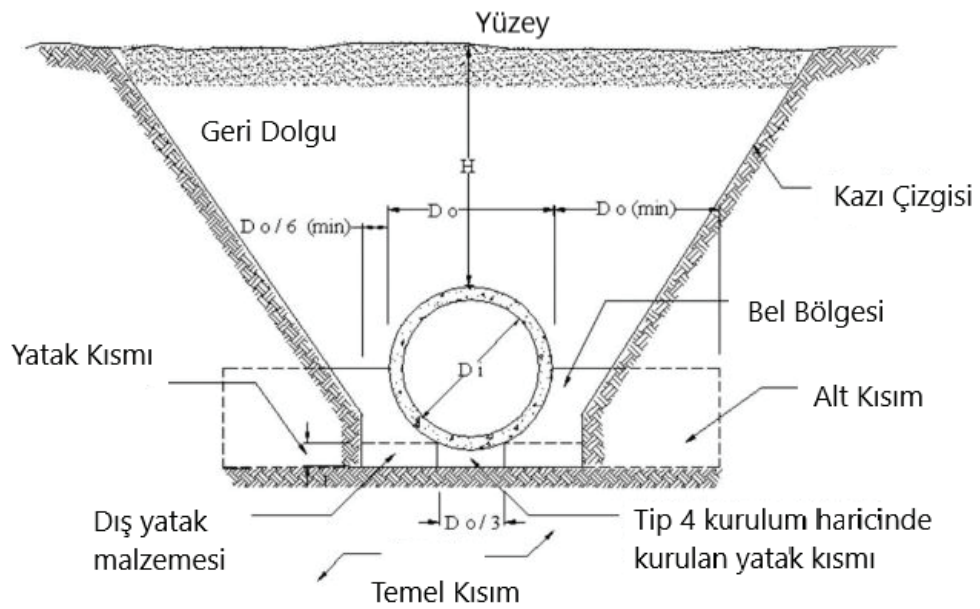

Şekil 2 - Standart hendek/dolgu kurulumu [11]

Tablo 1 - Standart boru gömülme durumları için kullanılan zemin türleri ve SIDD'de eşdeğer USCS ve AASHTO zemin sinıflandırma tanımları [12]

\begin{tabular}{|c|c|c|c|c|}
\hline \multirow{2}{*}{$\begin{array}{c}\text { Doğrudan } \\
\text { Tasarım Yöntemi } \\
\text { Zemin }\end{array}$} & \multicolumn{2}{|c|}{ Zemin Sınıflandırma Sistemi } & \multicolumn{2}{|c|}{ Kompaksiyon Derecesi (\%) } \\
\hline & USCS & $\begin{array}{c}\text { Standart } \\
\text { AASHTO }\end{array}$ & $\begin{array}{l}\text { Standart } \\
\text { Proktor }\end{array}$ & $\begin{array}{l}\text { Modifiye } \\
\text { Proktor }\end{array}$ \\
\hline \multirow{6}{*}{$\begin{array}{c}\text { Kategori I } \\
\text { Çakıllı kum }\end{array}$} & \multirow{6}{*}{$\begin{array}{l}\text { SW, SP, } \\
\text { GW, GP }\end{array}$} & \multirow{6}{*}{ A-1, A-3 } & 100 & 95 \\
\hline & & & 95 & 90 \\
\hline & & & 90 & 85 \\
\hline & & & 85 & 80 \\
\hline & & & 80 & 75 \\
\hline & & & 61 & 59 \\
\hline \multirow{6}{*}{$\begin{array}{l}\text { Kategori II } \\
\text { Kumlu silt }\end{array}$} & \multirow{6}{*}{$\begin{array}{c}\text { GM, SM, ML } \\
\text { \%20'sinden } \\
\text { daha azı } \\
\text { No. } 200 \text { 'den } \\
\text { geçen GC, SC }\end{array}$} & \multirow{6}{*}{$A-2, A-4$} & 100 & 95 \\
\hline & & & 95 & 90 \\
\hline & & & 90 & 85 \\
\hline & & & 85 & 80 \\
\hline & & & 80 & 75 \\
\hline & & & 49 & 46 \\
\hline
\end{tabular}


Tablo 1 - Standart boru gömülme durumları için kullanılan zemin türleri ve SIDD'de eşdeğer USCS ve AASHTO zemin sinıflandırma tanımları [12] (devam)

\begin{tabular}{|c|c|c|c|c|}
\hline \multirow{2}{*}{$\begin{array}{c}\text { Doğrudan } \\
\text { Tasarım Yöntemi } \\
\text { Zemin }\end{array}$} & \multicolumn{2}{|c|}{ Zemin Sınıflandırma Sistemi } & \multicolumn{2}{|c|}{ Kompaksiyon Derecesi (\%) } \\
\hline & USCS & $\begin{array}{c}\text { Standart } \\
\text { AASHTO }\end{array}$ & $\begin{array}{l}\text { Standart } \\
\text { Proktor }\end{array}$ & $\begin{array}{l}\text { Modifiye } \\
\text { Proktor }\end{array}$ \\
\hline \multirow{6}{*}{$\begin{array}{c}\text { Kategori III } \\
\text { Siltli kil }\end{array}$} & \multirow{6}{*}{$\begin{array}{c}\mathrm{CL}, \mathrm{MH}, \\
\mathrm{GC}, \mathrm{SC}\end{array}$} & \multirow{6}{*}{ A-5, A-6 } & 100 & 90 \\
\hline & & & 95 & 85 \\
\hline & & & 90 & 80 \\
\hline & & & 85 & 75 \\
\hline & & & 80 & 70 \\
\hline & & & 40 & 40 \\
\hline \multirow{4}{*}{$\begin{array}{c}\text { Kategori IV } \\
\text { Yüksek Plastisiteli } \\
\text { Kil }\end{array}$} & \multirow{4}{*}{$\mathrm{CH}$} & \multirow{4}{*}{ A7 } & 100 & 90 \\
\hline & & & 95 & 85 \\
\hline & & & 90 & 80 \\
\hline & & & 45 & 40 \\
\hline
\end{tabular}

ASCE 15-98 Şartnamesi, dolgu veya hendek koşullarında beton borunun yerleşimi ile ilgili dört adet kurulum yöntemi tanımlanmıştır (Tablo 2). Bu dört kurulum yöntemi; Tip 1, 2, 3 ve 4 hem dolgu hem de hendek tipi kurulumlar için standart olarak kullanılabilir. Bu kurulum tiplerinin her biri, üç sıkıştırma bölgesi için izin verilen malzeme kategorilerini ve bu bölge için uygun sıkıştırma derecesini tanımlar. Tip 1, en çok dikkat ve kontrol gerektiren en kaliteli kurulum iken Tip 4 ise en düşük kalitedeki kurulumu göstermektedir. Doğrudan tasarım (SIDD) Tip 4 kurulum uygulamasında, boru tabanında kaya olmadığı durumda yatak tabakası düzenlenmeden kötü derecelenmiş temel zemini üzerine beton boru yerleştirilebilmektedir. Bu tür uygulamalarda aktarılan dolgu ve trafik yüklerini boru kesiti taşıyacağı için, borunun yeterli dayanıma ve/veya rijitliğe ve duraylılığa sahip olması gerekmektedir. Dolayısıyla Tip 4 kurulum daha rijit bir boru gerektirmektedir. Çünkü dolgu malzemesi türü ve sıkıştırma kontrolü bakımından çok az veya hiç kontrol olmayan koşulları kapsamaktadır [13].

Nitelikli dolgu malzeme kaynaklarına uzak bölgelerde inşa edilecek boru hatlarının tasarımında, taşıma maliyetleri ekonomik olmayan imalatlara neden olmaktadır. Bu tür problemler araştırmacıları alternatif çözüm arayışlarına yöneltmiş ve doğrudan tasarım yönteminde (Standard Installation Direct Design-SIDD) gömülü boruların Tip 4 kurulum tipi ile kurulumunda yerel zeminin ince daneli zemin ve geri dolguda da ince daneli zeminlerin kullanılmasında boru davranışı araştırılmıştır. Wong vd. (2006)'da SIDD yöntemi ile Tip 4 kurulum standartları ile gömülmüş olan dört adet beton boruya ait arazi deneyinde, boruların kısa ve uzun süreli olarak davranışı incelenmiştir [14]. Bu kapsamda boruların etrafına gerilme ölçerler yerleştirilerek gerilmelerin zamana bağlı değişimi izlenmiş ve değerlendirilmiştir. 
Tablo 2 - Standart kurulum türleri ve minimum kompaksiyon oranları [12]

\begin{tabular}{|c|c|c|c|}
\hline $\begin{array}{c}\text { Kurulum } \\
\text { Tipi }\end{array}$ & Yatak & $\begin{array}{c}\text { Boru Alt } \\
\text { Yan Kısmındaki } \\
\text { Malzeme }\end{array}$ & $\begin{array}{c}\text { Hendek Duvarı } \\
\text { Alt Kısmındaki } \\
\text { Malzeme }\end{array}$ \\
\hline Tip 1 & $\begin{array}{c}75 \text { mm.'den küçük olmamak } \\
\text { şartıyla Do/24 } \\
\text { Tabanda kaya varsa } 150 \\
\text { mm.'den } \\
\text { küçük olmamak şartıyla } \\
\text { Do/12 }\end{array}$ & \%95 Kategori I & $\begin{array}{c}\% 90 \text { Kategori I } \\
\% 95 \text { Kategori II } \\
\% 100 \text { Kategori III }\end{array}$ \\
\hline Tip 2 & $\begin{array}{c}75 \text { mm.'den küçük olmamak } \\
\text { şartıyla Do/24 } \\
\text { Tabanda kaya varsa } 150 \\
\text { mm.'den } \\
\text { küçük olmamak şartıyla } \\
\text { Do/12 }\end{array}$ & $\begin{array}{l}\text { \%90 Kategori I } \\
\text { veya } \\
\% 95 \text { Kategori II }\end{array}$ & $\begin{array}{c}\text { \%85 Kategori I } \\
\% 90 \text { Kategori II } \\
\% 95 \text { Kategori III }\end{array}$ \\
\hline Tip 3 & $\begin{array}{c}75 \text { mm.'den küçük olmamak } \\
\text { şartıyla Do/24 } \\
\text { Tabanda kaya varsa } 150 \\
\text { mm.'den } \\
\text { küçük olmamak şartıyla } \\
\text { Do/12 }\end{array}$ & $\begin{array}{l}\% 85 \text { Kategori I } \\
\% 90 \text { Kategori II } \\
\% 95 \text { Kategori III }\end{array}$ & $\begin{array}{c}\% 85 \text { Kategori I } \\
\% 90 \text { Kategori II } \\
\% 95 \text { Kategori III }\end{array}$ \\
\hline Tip 4 & $\begin{array}{c}\text { Yatak gerekmez } \\
\text { (tabanda kaya yoksa) } \\
\text { Tabanda kaya varsa } 150 \\
\text { mm.'den } \\
\text { küçük olmamak şartıyla } \\
\text { Do/12 }\end{array}$ & $\begin{array}{c}\text { Kompaksiyon } \\
\text { gerekmez } \\
\text { (Kategori III } \\
\text { kullanılması } \\
\text { hariç) } \\
\text { \%85 Kategori III }\end{array}$ & $\begin{array}{c}\text { Kompaksiyon } \\
\text { gerekmez } \\
\text { (Kategori III } \\
\text { kullanılması } \\
\text { hariç) } \\
\text { \%85 Kategori III }\end{array}$ \\
\hline
\end{tabular}

Bu makalede, doğrudan tasarım yöntemi kapsamında Tip 4 kurulum koşullarında gömülen beton boruların tasarımı gerçekleştirilmiştir. Bu amaçla önce Wong vd. (2006) kapsamında yapılan Barrie sahası arazi deneyi, Plaxis 2D (2019) programı ile modellenmiş ve araziden alınan gerilme ölçümleri ile analiz hesap sonuçları karşılaştırılarak sayısal modelin doğrulaması yapılmıştır. Ayrıca sayısal analiz hesap sonuçları SIDD yöntemi ile Tip 4 kurulum için belirlenen kesit tesirleri ile de karşılaştırılmıştır. Barrie sahası sayısal modeli ve zemin koşulları dikkate alınarak farklı boru çapı ve gömülme derinlikleri için sayısal analizler tekrarlanmıştır. Analizlerden hesaplanan kesit tesirlerinden yararlanılarak farklı boru çapları ve gömülme derinlikleri için boru imalatında gerekli olan donatı miktarlarını gösteren bir abak elde edilmiştir. Ayrıca ülkemizde İller Bankası A.Ş’nin gömülü beton boru tasarımında yaygın olarak kullandığı gerekli donatı miktarlarının yeterli olup olmadığı incelenmiştir. 


\section{DOĞRUDAN TASARIM YÖNTEMI}

1970'li yıllarda ACPA (American Concrete Pipe Association - Amerikan Beton Boru Birliği) tarafından beton boru-zemin yerleşim performanslarını incelemek için uzun vadeli araştırma programları başlatılarak, beton boruların yapısal davranışı ve boru-zemin etkileşimleri incelenmiştir. Bu araştırmaların bir sonucu olarak standart yerleşim tipleri için Heger zemin basıncı dağılımı geliştirilmiştir (Şekil 3). Bu kapsamda, Tablo 1'de belirtilen zemin kategorileri ve Tablo 2'de verilen kurulum tipleri için Şekil 3'te gösterilen Heger toprak basıncı dağılımı kullanılabilmektedir.

Kurulum tipleri için boru etrafındaki gerilme dağılımlarının hesaplanmasında kullanılacak katsayılar Tablo 3'te sunulmuştur. A1-A6 katsayıları toprak basıncının boyutsuz düşey ve yatay bileşenleri, a - v ise boyutsuz düşey ve yatay gerilmeleri tanımlamak için kullanılan katsayılardır. Diğer katsayılar (d, h1 ve h2) ise (1), (2) ve (3) eşitliklerinden hesaplanabilir.

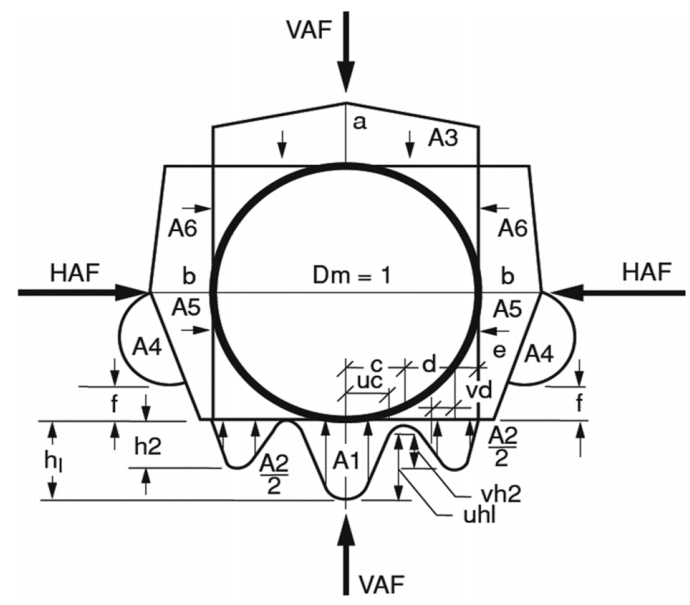

Şekil 3 - Doğrudan tasarım için Heger zemin basıncı dă̆llımı [12]

Tablo 3 - Kurulum tiplerine göre Heger toprak basıncı dağılımı katsayıları [12]

\begin{tabular}{ccccc}
\hline \multirow{2}{*}{ Katsaylar } & \multicolumn{4}{c}{ Kurulum Tipleri } \\
\cline { 2 - 5 } & Tip 1 & Tip 2 & Tip 3 & Tip 4 \\
\hline VAF & 1.35 & 1.40 & 1.40 & 1.45 \\
\hline HAF & 0.45 & 0.40 & 0.37 & 0.30 \\
\hline A1 & 0.62 & 0.85 & 1.05 & 1.45 \\
\hline A2 & 0.73 & 0.55 & 0.35 & 0.00 \\
\hline A3 & 1.35 & 1.40 & 1.40 & 1.45 \\
\hline A4 & 0.19 & 0.15 & 0.10 & 0.00 \\
\hline A5 & 0.08 & 0.08 & 0.10 & 0.11
\end{tabular}


Tablo 3 - Kurulum tiplerine göre Heger toprak basıncı dă̆ılımı katsayıları [12] (devam)

\begin{tabular}{ccccc}
\hline \multirow{2}{*}{ Katsaylar } & \multicolumn{5}{c}{ Kurulum Tipleri } \\
\cline { 2 - 5 } & Tip 1 & Tip 2 & Tip 3 & Tip 4 \\
\hline A6 & 0.18 & 0.17 & 0.17 & 0.19 \\
a & 1.40 & 1.45 & 1.45 & 1.45 \\
b & 0.40 & 0.40 & 0.36 & 0.30 \\
c & 0.18 & 0.19 & 0.20 & 0.25 \\
e & 0.08 & 0.10 & 0.12 & 0.00 \\
f & 0.05 & 0.05 & 0.05 & - \\
u & 0.80 & 0.82 & 0.85 & 0.90 \\
v & 0.80 & 0.70 & 0.60 & - \\
\hline
\end{tabular}

$d=0.5-c-e$

$h_{1}=\frac{(1.5 A 1)}{[c(1+u)]}$

$h_{2}=\frac{(1.5 A 2)}{[d(1+u)+2 e]}$

Doğrudan tasarım yönteminde gerekli boru donatı alanı, boruya etkiyen gerilmelere bağlı olarak hesaplanan moment (M), eksenel kuvvet $(\mathrm{N})$ ve kesme kuvveti (V) dikkate alınarak belirlenir. $\mathrm{Bu}$ kesit tesirleri Tablo 4'te Tip 4 kurulum için verilen katsayılardan yararlanılarak veya boru-zemin etkileşimini dikkate alan sayısal analizlerden hesaplanabilir. M, N ve V değerlerini hesaplamak için sırasıyla (4), (5) ve (6) eşitlikleri verilmiştir [6]. Diğer kurulum tipleri için de ASCE 15-98'den yararlanılarak belirlenecek boru analiz katsayıları kullanılarak kesit tesirleri hesaplanabilir. Tablo 4'te Tip 4 kurulum için farklı dış yük uygulamalarındaki katsayılar sunulmuştur [12].

$\mathrm{M}=\frac{\mathrm{C}_{\mathrm{mi}} \times \mathrm{W}_{\mathrm{i}} \times \mathrm{D}_{\mathrm{m}}}{2}$

$\mathrm{N}=\mathrm{C}_{\mathrm{ni}} \times \mathrm{W}_{\mathrm{i}}$

$\mathrm{V}=\mathrm{C}_{\mathrm{vi}} \times \mathrm{W}_{\mathrm{i}}$

Burada; $\mathrm{C}_{\mathrm{mi}}=$ Moment hesabı için boru analiz katsayısı, $\mathrm{C}_{\mathrm{ni}}=$ Eksenel kuvvet hesabı için boru analiz katsayısı, $\mathrm{C}_{\mathrm{vi}}=$ Kesme kuvveti hesabı için boru analiz katsayısı, $\mathrm{W}_{\mathrm{i}}=$ Boru üzerine etkiyen yüklerin toplamı, $\mathrm{D}_{\mathrm{m}}=$ Boru ortalama çapını temsil etmektedir. 
Tablo 4 - Tip 4 kurulum için boru analiz katsayıları (ASCE 15-98) [12]

\begin{tabular}{|c|c|c|c|c|}
\hline Lokasyon & Yük Tipi & Cmi & Cni & Cvi \\
\hline \multirow{5}{*}{ Boru alt } & $\mathrm{Wp}$ & 0.235 & 0.077 & \multirow{5}{*}{-} \\
\hline & $\mathrm{We}$ & 0.131 & 0.128 & \\
\hline & Wf & 0.160 & -0.403 & \\
\hline & WL1 & 0.185 & 0.152 & \\
\hline & WL2 & 0.237 & -0.004 & \\
\hline \multirow{5}{*}{ Boru üst } & $\mathrm{Wp}$ & 0.079 & -0.077 & \multirow{5}{*}{-} \\
\hline & $\mathrm{We}$ & 0.118 & 0.079 & \\
\hline & Wf & 0.076 & -0.232 & \\
\hline & WL1 & 0.110 & 0.114 & \\
\hline & WL2 & 0.255 & 0.004 & \\
\hline \multirow{5}{*}{ Boru yan duvar } & $\mathrm{Wp}$ & -0.101 & -0.287 & \multirow{5}{*}{-} \\
\hline & $\mathrm{We}$ & -0.127 & 0.504 & \\
\hline & Wf & -0.095 & -0.057 & \\
\hline & WL1 & -0.121 & 0.495 & \\
\hline & WL2 & -0.168 & 0.492 & \\
\hline \multirow{4}{*}{ Kritik kesme } & $\mathrm{Wp}$ & \multirow{4}{*}{ - } & 0.188 & 0.431 \\
\hline & $\mathrm{We}$ & & 0.211 & 0.309 \\
\hline & Wf & & -0.323 & 0.284 \\
\hline & WL1 & & 0.229 & 0.305 \\
\hline
\end{tabular}

Doğrudan tasarım yönteminde donatı gereksinimi, ilgili zemin parametreleri ve standart kurulum tiplerine bağlı olarak verilen analiz katsayıları ile zemin yüklerinin belirlenmesi ve tesir kuvvetlerinin hesaplanmasıyla elde edilir. Tablo 4'teki $\mathrm{W}_{\mathrm{e}}$ boru üzerindeki zemin yükünü, $\mathrm{W}_{\mathrm{p}}$ borunun kendi ağırlığından dolayı oluşacak yükü, $\mathrm{W}_{\mathrm{f}}$ varsa akışkan yükünü ve varsa hareketli yükler WL1 ve WL2'yi ifade etmektedir.

Heger basınç dağılımları kapsamında Tablo 3 'te verilen düşey kemerlenme faktörü (VAF) ve yatay kemerlenme faktörü (HAF) doğrudan tasarım yönteminde toprak basıç̧larının hesaplanmasında kullanılır. Tasarımda dikkate alınacak gerçek düşey ve yatay yükler bu kemerlenme faktörleri ile çarpılarak belirlenir. Prizma yükü (PL) borunun üzerindeki zemin örtüsünün ağırlığıdır ve uluslararası birim sistemine göre Eşitlik (7) ile hesaplanır. Boru üzerine etkiyen toplam zemin yükü (W), prizma yükünün (PL), VAF ile çarpımı sonucu Eşitlik (8) ile belirlenir.

$$
\begin{aligned}
& \mathrm{PL}=\left(\frac{\mathrm{w} \cdot \mathrm{D}_{\mathrm{o}}}{1000}\right) \cdot\left(\mathrm{H}+\left(\frac{0.107 \cdot \mathrm{D}_{\mathrm{o}}}{1000}\right)\right) \\
& \mathrm{W}=\mathrm{PLxVAF}
\end{aligned}
$$


Burada; PL= Prizma yükü $(\mathrm{kN} / \mathrm{m}), \mathrm{w}=$ zemin birim hacim ağırlığ $\left(\mathrm{kN} / \mathrm{m}^{3}\right), \mathrm{D}_{0}=$ borunun dış çapı (mm), H=borunun üst kısmındaki dolgu yüksekliği (m)'ni göstermektedir.

Boru üzerine etkiyen trafik yükü boru çapına ve dolgu yüksekliğine $(\mathrm{H})$ bağlı olarak Tablo 5 yardımıyla hesaplanabilir. Doğrudan tasarım yönteminde $2.734 \mathrm{~m}$ dolgu kalınlığından daha derine gömülen borulara trafik yükünün etkisi olmadığı belirtilmiştir [15].

Tablo 5 - Boru üzerindeki dolgu yüksekliğine bă̆lı trafik yükü [15]

\begin{tabular}{|c|c|c|c|c|c|c|c|c|c|}
\hline \multirow{2}{*}{$\begin{array}{c}\text { Boru } \\
\text { Çapı } \\
(\mathrm{m}) \\
\end{array}$} & \multicolumn{9}{|c|}{ Boru üzerindeki dolgu yüksekliği H (m) } \\
\hline & 0.305 & 0.610 & 0.914 & 1.219 & 1.524 & 1.829 & 2.134 & 2.438 & 2.743 \\
\hline 0.38 & 34.44 & 18.68 & 9.63 & 6.57 & 5.11 & 4.09 & 3.36 & 2.77 & 2.34 \\
\hline 0.46 & 38.09 & 21.31 & 10.95 & 7.59 & 5.84 & 4.67 & 3.79 & 3.21 & 2.77 \\
\hline 0.53 & 41.15 & 23.64 & 12.26 & 8.46 & 6.57 & 5.25 & 4.38 & 3.65 & 3.06 \\
\hline 0.61 & 43.93 & 25.98 & 13.57 & 9.34 & 7.30 & 5.84 & 4.82 & 4.09 & 3.50 \\
\hline 0.69 & 42.91 & 28.17 & 14.74 & 10.22 & 8.17 & 6.42 & 5.25 & 4.38 & 3.79 \\
\hline 0.76 & 41.30 & 30.21 & 15.76 & 10.95 & 8.61 & 7.01 & 5.69 & 4.82 & 4.09 \\
\hline 0.84 & 42.76 & 32.11 & 16.93 & 11.82 & 9.19 & 7.44 & 6.13 & 5.25 & 4.38 \\
\hline 0.91 & 41.01 & 34.00 & 17.95 & 12.55 & 9.78 & 8.03 & 6.57 & 5.55 & 4.82 \\
\hline 0.99 & 38.97 & 35.61 & 18.83 & 13.28 & 10.36 & 8.46 & 7.01 & 5.98 & 5.11 \\
\hline 1.07 & 37.21 & 37.36 & 19.85 & 13.86 & 10.95 & 8.90 & 7.44 & 6.28 & 5.40 \\
\hline 1.22 & 34.00 & 36.19 & 21.45 & 15.18 & 11.97 & 9.78 & 8.17 & 6.86 & 5.98 \\
\hline 1.37 & 31.38 & 34.44 & 23.06 & 16.35 & 12.99 & 10.65 & 8.90 & 7.59 & 6.42 \\
\hline 1.52 & 29.04 & 32.84 & 24.52 & 17.37 & 13.86 & 11.38 & 9.49 & 8.17 & 7.01 \\
\hline 1.68 & 27.00 & 31.52 & 23.93 & 18.39 & 14.74 & 12.11 & 10.22 & 8.61 & 7.44 \\
\hline 1.83 & 25.25 & 31.96 & 22.91 & 19.41 & 15.47 & 12.84 & 10.80 & 9.19 & 7.88 \\
\hline 1.98 & 23.79 & 32.69 & 22.18 & 20.29 & 16.20 & 13.43 & 11.38 & 9.63 & 8.32 \\
\hline 2.13 & 22.47 & 33.42 & 21.31 & 19.85 & 16.93 & 14.01 & 11.82 & 10.07 & 8.76 \\
\hline
\end{tabular}

Bilgi ve Notlar: Ham zemin üzerine uygulandığı varsayılmıştır. AASHTO HS20 kamyon yüküne göre hesaplanmıştır. 3.05 metre ve üzerindeki dolgu yüksekliklerinde araç yükü ihmal edilmiştir. Yük birimi kN/m'dir.

\section{BARRIE SAHASI ARAZİ DENEYİ}

Bu çalışma kapsamında, Wong vd. (2006)'da Ontario'da yer alan Barrie sahasında yapılan bir arazi deneyinden alınan gerilme ölçümleri dikkate alınarak sayısal modelin doğrulaması yapılmıştır. Şekil 4'te gösterilen hendek kesitinde ortalama hendek derinliği $2.5 \mathrm{~m}$ 'dir. Arazi deney alanında, temel zemini kötü derecelenmiş siltli kum ve geri dolgu zemini 
düşük miktarda ince dane içeren iyi derecelenmiş çakıllı kum olarak belirtilmiştir. Yerel zeminin doğal su muhtevası kazı derinliği boyunca $\% 2$ ve $\% 5$ arasında değişim göstermektedir [16]. Yerel zemin için maksimum standart proktor yoğunluğu $1725 \mathrm{~kg} / \mathrm{m}^{3}$, optimum su muhtevası ise \%10'dur [17]. Boru iç çapı 600mm, dış çap1 800mm olup boru uzunluğu 2.44m'dir. Arazi deneyi verileri Tablo 6'da sunulmuştur.
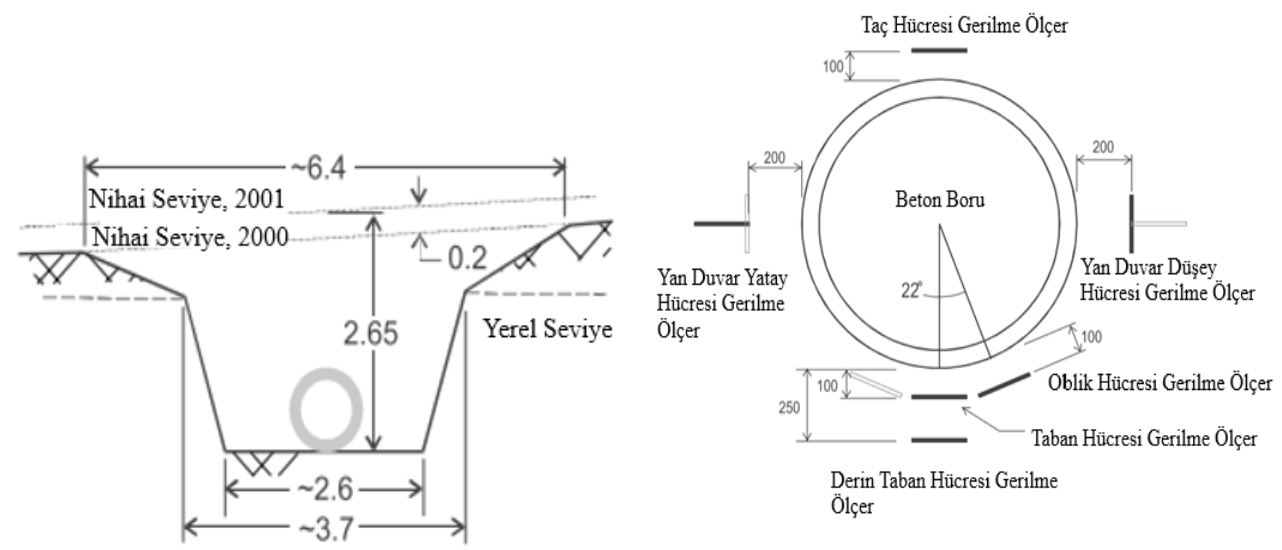

Şekil 4 - Barrie deney sahası (a) kazı kesiti (ölçüler m) (b) gerilme ölçerlerin yerleşimi [14]

Tablo 6 - Barrie sahası arazi deney verileri [14]

\begin{tabular}{ll}
\hline Geri dolgu & İnce dane barındıran iyi derecelenmiş çakıllı kum \\
\hline Yatak & Kötü derecelenmiş siltli kum \\
\hline Toplam kazı derinliği (m) & 2.5 \\
\hline Boru iç çapı (Di) (mm) & 600 \\
\hline Boru dış çapı (Do) (mm) & 800 \\
\hline Zemin birim hacim ağırlığı $\left(\mathrm{kN} / \mathrm{m}^{3}\right)$ & 16.91 \\
\hline YASS (m) & - \\
\hline Boru uzunluğu $(\mathrm{m})$ & 2.44 \\
\hline
\end{tabular}

Arazi deneyinde boru, Şekil 4'te gösterilen kazı kesitinde Tip 4 kurulum koşullarında gömülmüştür. Bu kapsamda, $2.65 \mathrm{~m}$ derinlikte ve $6.4 \mathrm{~m}$ genişlikte şevli bir kazı yapılmıştır (Şekil 4a). Hendek tabanında kaya zemin olmadığı için özel bir yatak tabakası yapılmamış, boru arazide kötü derecelenmiş siltli kum zemin üzerine oturtulmuştur (Tip 4 kurulumda yatak gerekmemektedir). Ardından gerilme ölçerler borunun çevresine gömülme sırasında Şekil 4b'de gösterildiği gibi konumlandırılmıştır. Geri dolgu sırasında gerilme ölçerlerin zarar görmesini engellemek için kum yastıklar kullanılmıştır. Gerilme ölçerler, borunun yatay simetri ekseninde sağ ve sol tarafına biri düşey biri yatay gerilmeyi ölçmek üzere $0.2 \mathrm{~m}$ mesafede, oblik hücre $0.1 \mathrm{~m}$ mesafede, boru taç ve taban bölgesinde $0.1 \mathrm{~m}$ mesafede 
konumlandırılmıştır. Boru tabanına önce gerilme ölçer yerleştirilmiş, daha sonra üzerine beton boru konulmuştur. Hendek içine yerleştirilen borunun etrafı düşük miktarda ince dane içeren iyi derecelenmiş çakıllı kum dolgu ile adım adım kapatılırken gerilme ölçerlerden okumalar alınmıştır. Boru tamamen geri dolgu ile kapatıldıktan sonra da adım adım dolgu yerleşimine devam edilerek istenilen seviyeye kadar dolgu gerçekleştirilmiştir.

\subsection{SIDD Tip 4 Yerleşime Göre Boru Kesit Tesirleri Hesabı}

Bölüm 2'de detayları belirtilen SIDD yöntemine göre boru üzerine etkiyen yükler ve kesit tesirleri hesaplanmıştır. Doğrudan tasarım yöntemine göre öncelikle boru üzerindeki Prizma Yükü (PL) eşitlik (7) ve Tip 4 kurulum için VAF=1.45 dikkate alınarak eşitlik (8)'den dolgu zemin yükü (W) $37.97 \mathrm{kN} / \mathrm{m}$ olarak hesaplanmıştır. Doğrudan tasarım yöntemine göre boru taç, yan duvar ve taban kısmında, zemin ve trafik yükünden dolayı oluşacak moment ve normal kuvvet değerleri hesaplanarak Tablo 7'de sunulmuştur.

Tablo 7 - SIDD yöntemine göre boru üzerine etkiyen kesit tesirleri

\begin{tabular}{ccccccc}
\hline & \multicolumn{2}{c}{ Boru tacı } & \multicolumn{2}{c}{ Boru yan duvarı } & \multicolumn{2}{c}{ Boru tabanı } \\
\hline & $\begin{array}{c}\text { Moment } \\
(\mathrm{kNm} / \mathrm{m})\end{array}$ & $\begin{array}{c}\text { Eksenel } \\
\text { kuvvet } \\
(\mathrm{kN} / \mathrm{m})\end{array}$ & $\begin{array}{c}\text { Moment } \\
(\mathrm{kNm} / \mathrm{m})\end{array}$ & $\begin{array}{c}\text { Eksenel } \\
\text { kuvvet } \\
(\mathrm{kN} / \mathrm{m})\end{array}$ & $\begin{array}{c}\text { Moment } \\
(\mathrm{kNm} / \mathrm{m})\end{array}$ & $\begin{array}{c}\text { Eksenel } \\
\mathrm{kuvvet} \\
(\mathrm{kN} / \mathrm{m})\end{array}$ \\
\hline $\begin{array}{c}\text { Zemin } \\
\text { yükünden } \\
(\mathrm{We})\end{array}$ & 1.79 & 2.99 & -1.92 & 19.13 & 1.98 & 4.86 \\
\hline $\begin{array}{c}\text { Taşıt } \\
\text { yükünden } \\
\left(\mathrm{W}_{\mathrm{L}}\right)\end{array}$ & 0.31 & 0.81 & -0.34 & 3.52 & 0.53 & 1.08 \\
\hline Toplam & 2.10 & 3.80 & -2.26 & 22.65 & 2.52 & 5.94 \\
\hline
\end{tabular}

\subsection{Sayısal Modelin Doğrulaması}

Şekil 4'te gösterilen arazi deneyi hendek kesitinin, boru özellikleri ve yükleme koşulları dikkate alınarak sayısal analizi Plaxis 2D (2019) programı kullanılarak gerçekleştirilmiştir. Analizlerde zemin davranışı Hardening - Soil (HS) bünye bağıntısı dikkate alınarak, betonarme boru ise eğilme rijitliği (EI) ve eksenel rijitlik (EA) parametreleri ile elastik olarak modellenmiştir. Sayısal analizler iki boyutlu olarak düzlem şekil değiştirme koşulları dikkate alınarak gerçekleştirilmiştir. Sahada yeraltı suyu bulunmamaktadır. Trafik yükü olarak ACPA Design Data 5, 2011'teki HS20 trafik yükü, boru dış çap1 $0.8 \mathrm{~m}$ ve dolgu yüksekliği yaklaşık $2 \mathrm{~m}$ dikkate alınarak tasarım çizgisel yükü $7.11 \mathrm{kN} / \mathrm{m}$ olarak Tablo 5 'ten belirlenmiştir [15]. Analizlerde boru tabanında yer alan temel zemini, yerel zemin ve geri dolgu zeminlere ait malzeme parametreleri Tablo 8'de sunulmuştur. Şekil 5'te Barrie sahası arazi kesiti için sayısal analizlerde kullanılan sonlu elemanlar modeli gösterilmiştir. Analizlerde 4, 5, 8, 9, 10 ve 11. yükleme adımlarında sıkıştırma etkisini dikkate almak için 
$15 \mathrm{kN} / \mathrm{m}$ 'lik bir yük ve 13 . yükleme adımında ise $7 \mathrm{kN} / \mathrm{m}$ 'lik bir yük uygulanmıştır. Sayısal analizlerde yükleme adımlarında etkitilen yükler Tablo 9'da gösterilmiştir. Sayısal analizden elde edilen hesap sonuçları ile arazi deneyinde alınan ölçümler farklı sonlu elemanlar ağı sıkılıkları da göz önünde bulundurulup karşılaştırılarak sayısal modelin doğrulaması yapılmıştır. Analizlerde boru ve zemin arasında ara-yüzey eleman kullanılarak ara-yüzey eleman katsayısı Rint $=0.80$ olarak dikkate alınmıştır.

Tablo 8 - Hardening - Soil zemin parametreleri

\begin{tabular}{lccccc}
\hline Parametre & Sembol & Birim & $\begin{array}{c}\text { Yerel } \\
\text { zemin }\end{array}$ & $\begin{array}{c}\text { Temel } \\
\text { zemini }\end{array}$ & $\begin{array}{c}\text { Geri } \\
\text { Dolgu }\end{array}$ \\
\hline Birim hacim ağırlık & $\gamma$ & $\mathrm{kN} / \mathrm{m}^{3}$ & 17 & 18 & 17 \\
\hline Referans Elastisite Modulü & $\mathrm{E}_{50}{ }^{\text {ref }}$ & $\mathrm{MPa}$ & 40 & 10 & 30 \\
\hline Referans Ödometre Modulü & $\mathrm{E}_{\text {oed }}{ }^{\text {ref }}$ & $\mathrm{MPa}$ & 40 & 10 & 30 \\
\hline $\begin{array}{l}\text { Referans Yükleme-boşaltma } \\
\text { Elastisite Modulü }\end{array}$ & $\mathrm{E}_{\mathrm{ur}}^{\text {ref }}$ & $\mathrm{MPa}$ & 120 & 30 & 90 \\
\hline Üstel malzeme sabiti & $\mathrm{m}$ & - & 0.5 & 0.5 & 0.5 \\
\hline Kohezyon & $\mathrm{c}^{\text {ref }}$ & $\mathrm{kN} / \mathrm{m}^{2}$ & 16 & 10 & 2 \\
\hline İçsel sürtünme açıs & $\phi$ & $\left(^{\circ}\right)$ & 37 & 30 & 30 \\
\hline Poisson oranı & $v_{\mathrm{ur}}$ & - & 0.2 & 0.2 & 0.2 \\
\hline Referans gerilme & $\mathrm{p}^{\text {ref }}$ & $\mathrm{kN} / \mathrm{m}^{2}$ & 100 & 100 & 100 \\
\hline Göçme oranı & $\mathrm{R}_{\mathrm{f}}$ & - & 0.90 & 0.90 & 0.9 \\
\hline
\end{tabular}

Tablo 9 - Sayısal analizlerde yükleme adımlarında etkitilen yükler

\begin{tabular}{ccc}
\hline Yükleme Adımları & $\begin{array}{c}\text { Sıkıştırma Yükü } \\
(\mathrm{kN} / \mathrm{m})\end{array}$ & $\begin{array}{c}\text { Tasarım Çizgisel Yükü } \\
(\mathrm{kN} / \mathrm{m})\end{array}$ \\
\hline Adım 4 & 15 & - \\
\hline Adım 5 & 15 & - \\
\hline Adım 8 & 15 & - \\
\hline Adım 9 & 15 & - \\
\hline Adım 10 & 15 & - \\
\hline Adım 11 & 15 & 7 \\
\hline Adım 13 & - &
\end{tabular}


Sayısal analiz sonuçlarına ağ sıkılığının etkisini belirlemek için orta ve ince sıkılıkta oluşturulan sonlu eleman ağları için analizler tekrarlanmış ve hesap sonuçları Tablo 10'da sunularak arazi ölçümleri ile karşılaştırılmıştır. Görüldüğü gibi hesap sonuçları arazide ölçülen gerilmelere oldukça yakındır. Şekil 6'da sayısal analiz sonucunda elde edilen düşey gerilme dağılımı gösterilmiştir. Boru çevresinde en yüksek gerilmenin taban bölgesinde oluştuğu görülmektedir. Bu sonuç, Şekil 3 'te gösterilen Heger zemin basıncı dağılımı ile de uyumludur. Borunun taban bölgesinde gerilme konsantrasyonu meydana gelmiştir. Sayısal analizden ve SIDD yöntemine göre Tablo 3 ve Tablo 4 kullanılarak Eşitlik (4) ve (5)'ten kesit tesirleri hesaplanmış ve Tablo 11 'de sunulmuştur. Görüldüğü gibi doğrudan tasarım (SIDD) ve sayısal analizlerden elde edilen kesit tesirleri arasında eğilme momentlerinde ve eksenel kuvvetlerde boru taç bölgesinde yaklaşık 2 kat, taban bölgesinde ise yaklaşık 1.5 kat fark bulunmuştur.

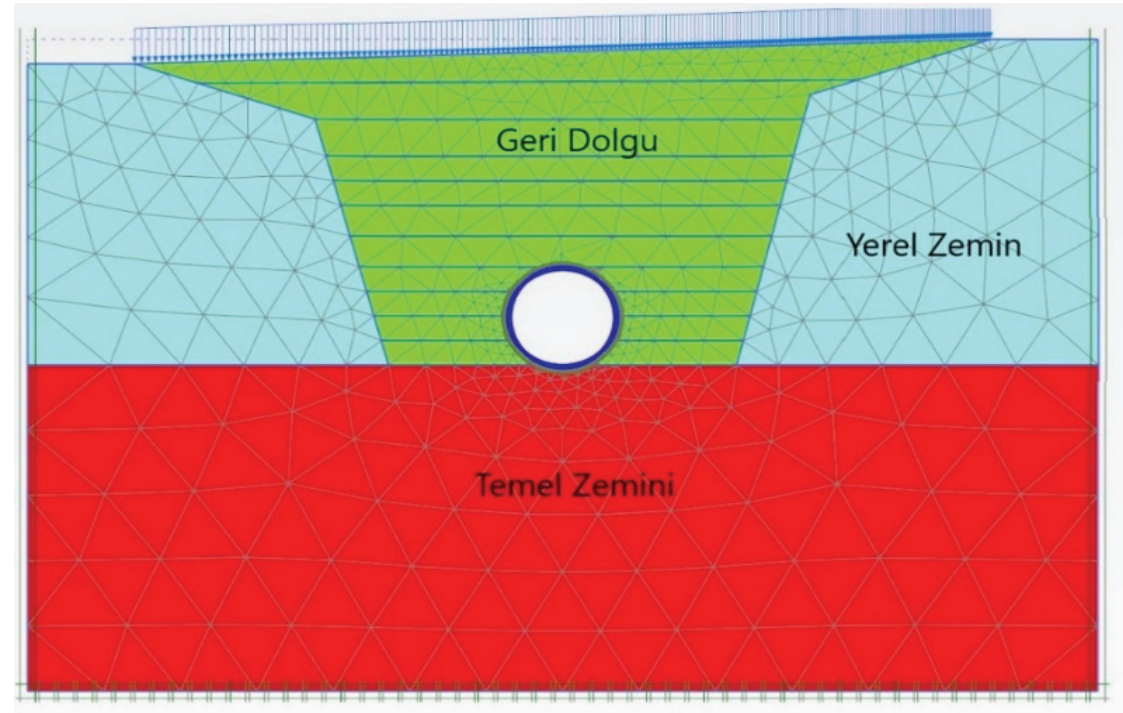

Şekil 5 - Barrie sahası arazi deneyi kesiti sayısal modeli (orta sıkı ăg)

Tablo 10 - Ölçülen ve hesaplanan gerilmelerin karşılaştırılması

\begin{tabular}{c|c|c|c}
\hline $\begin{array}{c}\text { Gerilmeler } \\
(\mathbf{k P a})\end{array}$ & $\begin{array}{c}\text { Barrie arazi deneyinde } \\
\text { ölçülen gerilme [8] }\end{array}$ & \multicolumn{2}{c}{$\begin{array}{c}\text { Plaxis 2B } \\
\text { Sayısal Analiz }\end{array}$} \\
\hline Ă̆ Sıkılığı & - & Orta & İnce \\
\hline Taç & 38 & 40 & 40.2 \\
\hline Taban & 110 & 93 & 94 \\
\hline Oblik & 39 & 36 & 38.8 \\
\hline Yan duvar (yatay) & 22 & 17 & 19.3 \\
\hline Yan duvar (düşey) & 54 & 39 & 39.7 \\
\hline
\end{tabular}




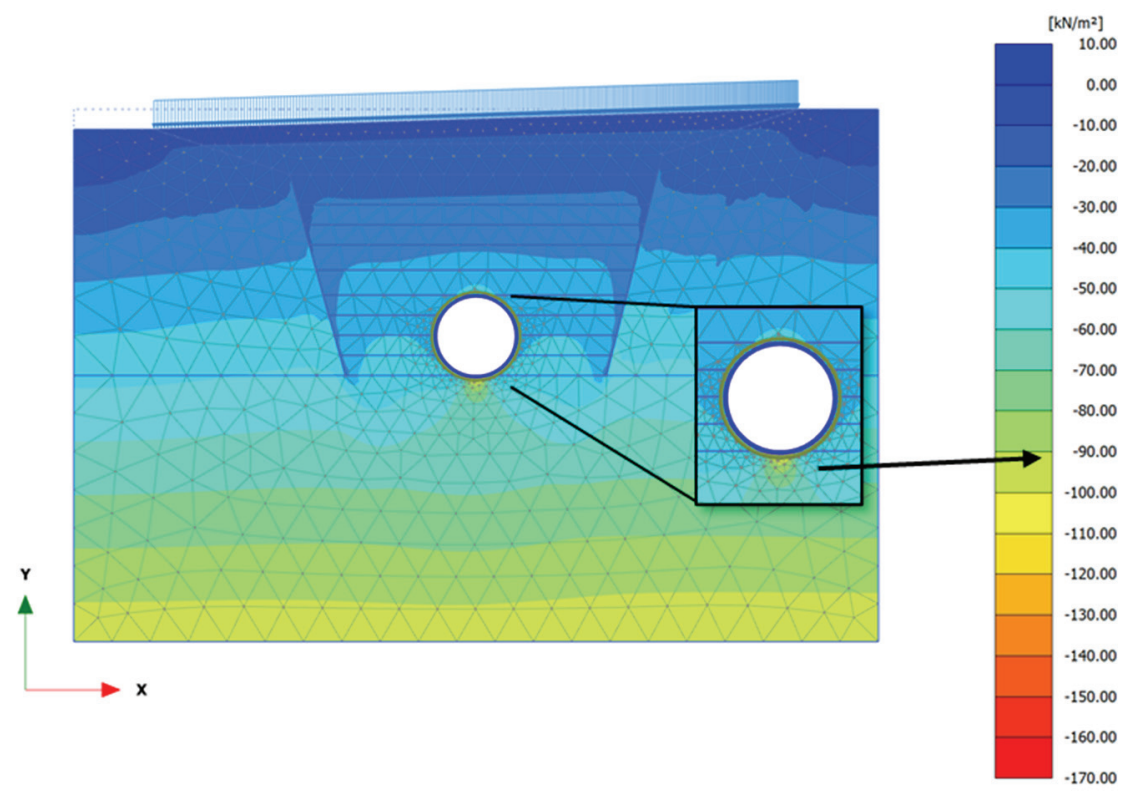

Şekil 6 - Sayısal modelde elde edilen düssey gerilme dă̆ılımı

Tablo 11 - SIDD yöntemi ve sayısal analizden hesaplanan kesit tesirlerinin karşılaştırılması

\begin{tabular}{|c|c|c|c|c|c|c|}
\hline \multirow{2}{*}{$\begin{array}{c}\text { Kesit } \\
\text { Tesirleri }\end{array}$} & \multicolumn{3}{|c|}{$\begin{array}{c}\text { Doğrudan Yöntem } \\
\text { (SIDD) Tip } 4 \text { kurulum }\end{array}$} & \multicolumn{3}{|c|}{$\begin{array}{c}\text { Plaxis 2B } \\
\text { Sayısal Analiz }\end{array}$} \\
\hline & Taç & Taban & $\begin{array}{c}\text { Yan } \\
\text { duvar }\end{array}$ & Taç & Taban & $\begin{array}{c}\text { Yan } \\
\text { duvar }\end{array}$ \\
\hline $\begin{array}{l}\text { Eğilme momenti } \\
\qquad(\mathrm{kNm} / \mathrm{m})\end{array}$ & 2.10 & 2.52 & -2.26 & 1.2 & 1.60 & -1.52 \\
\hline $\begin{array}{l}\text { Eksenel kuvvet } \\
(\mathrm{kN} / \mathrm{m})\end{array}$ & 3.80 & 5.94 & 22.65 & 8.08 & 9.69 & -21.1 \\
\hline
\end{tabular}

\section{PARAMETRIK SAYISAL ANALIZLER ve KESITT TESÍRLERİ}

$\mathrm{Bu}$ makale kapsamında, özellikle nitelikli dolgu malzemesine ulaşılamadığ durumlar için Tip 4 kurulum koşullarında beton boru davranışı zemin-yapı etkileşimi dikkate alınarak Plaxis 2D (2019) sonlu elemanlar programı ile analiz edilmiştir. Sayısal analizler orta (medium) ve ince (fine) sonlu elemanlar ağı ile ayrı ayrı yapılarak ağ sıkılığının analiz sonuçlarına etkisi de araştırılmıştır.

Şekil 5'te gösterilen sonlu eleman modelinde boru çapı ve dolgu yüksekliği değişiminin boru tasarımına etkileri sayısal analizler ile incelenmiştir. Bu kapsamda boru çap1 $600 \mathrm{~mm}$ ile $2000 \mathrm{~mm}$ arasında ve dolgu yüksekliği ise $2 \mathrm{~m}, 4 \mathrm{~m}, 6 \mathrm{~m}$ ve $8 \mathrm{~m}$ dikkate alınarak sayısal analizler tekrarlanmıştır. Şekil 7'de gösterilen sayısal model ile yapılan parametrik 
analizlerde, boru dış çapı $200 \mathrm{~mm}$ olarak artırılırken model geometrisinde hendek taban genişliği modelde daralma yaratmamak ve bu genişliğin etkisinin analiz sonuçlarını etkilememesi için x ekseninde 100'er mm kaydırılarak sabit tutulmuştur. Analizlerde boru çapı ve dolgu yüksekliği değişimlerine karşılık olarak elde edilen en yüksek momentler Tablo 12'de, en yüksek eksenel kuvvetler ise Tablo 13'te sunulmuştur. Şekil 8'de görüldüğü üzere, parametrik analizlerde sonlu elemanlar ağı sıkılığının ortadan inceye doğru iyileştirilmesi sonucunda elde edilen iç kuvvetlerin (eğilme momenti ve eksenel kuvvet) de karşılaştırılması yapılarak sunulmuştur. Büyük çaplı boruda kesit tesirlerini daha az etkilerken, küçük çaplı boruda kesit tesirlerine daha fazla etkisi olduğu ve moment değerlerini yaklaşık olarak \%40, eksenel kuvvet değerlerini ise \%15 oranında arttırdığı görülmüştür.

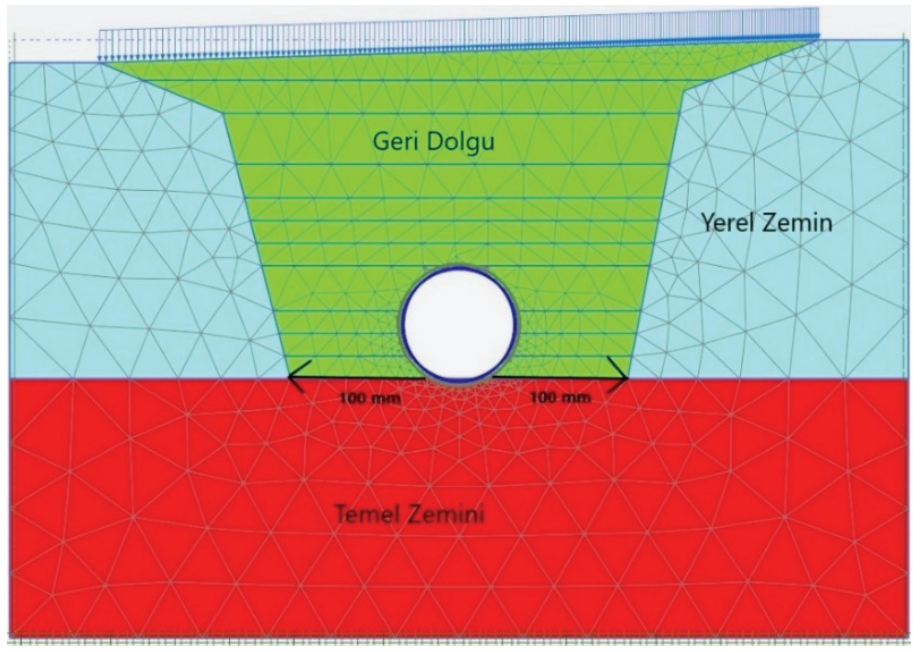

Şekil 7 - Sayısal analizlerde model geometrisi değişimi

Tablo 12 - Parametrik sayısal analizlerdeki en yüksek moment değerleri

\begin{tabular}{|c|c|c|c|c|c|c|c|c|}
\hline \multirow{4}{*}{$\begin{array}{c}\text { Boru Çapı } \\
\text { (mm) }\end{array}$} & \multicolumn{8}{|c|}{ Sayısal analizlerden belirlenen en yüksek moment $(\mathrm{kNm} / \mathrm{m})$} \\
\hline & \multicolumn{8}{|c|}{ Dolgu Yüksekliği H(m) } \\
\hline & \multicolumn{2}{|c|}{$2 \mathrm{~m}$} & \multicolumn{2}{|c|}{$4 \mathrm{~m}$} & \multicolumn{2}{|c|}{$6 \mathrm{~m}$} & \multicolumn{2}{|c|}{$8 \mathrm{~m}$} \\
\hline & Orta & İnce & Orta & İnce & Orta & İnce & Orta & İnce \\
\hline$\varnothing 600$ & 0.8 & 1.2 & 1.2 & 1.8 & 1.6 & 2.5 & 1.9 & 2.8 \\
\hline$\varnothing 800$ & 1.6 & 2.3 & 2.4 & 3.5 & 3.3 & 4.8 & 3.8 & 5.5 \\
\hline$\varnothing 1000$ & 2.7 & 3.8 & 4.1 & 5.8 & 5.4 & 7.9 & 6.1 & 9.2 \\
\hline$\varnothing 1200$ & 4.2 & 5.8 & 6.1 & 8.7 & 8.1 & 11.8 & 9.5 & 13.7 \\
\hline$\varnothing 1400$ & 7.5 & 9.8 & 8.4 & 12.1 & 11.4 & 16.4 & 13.2 & 19.2 \\
\hline$\varnothing 1600$ & 8.2 & 11.1 & 11.3 & 16.1 & 15.2 & 21.8 & 17.7 & 25.7 \\
\hline$\varnothing 1800$ & 10.7 & 14.4 & 14.5 & 20.7 & 19.4 & 27.9 & 22.6 & 32.9 \\
\hline$\varnothing 2000$ & 13.5 & 18 & 18.2 & 25.9 & 24.2 & 34.7 & 29.8 & 41 \\
\hline
\end{tabular}


Tablo 13 - Parametrik sayısal analizlerdeki en yüksek eksenel kuvvet değerleri

\begin{tabular}{|c|c|c|c|c|c|c|c|c|}
\hline \multirow{4}{*}{$\begin{array}{c}\begin{array}{c}\text { Boru Çapı } \\
(\mathbf{m m})\end{array} \\
\text { A ğ Sıkılı̆̆ } 1\end{array}$} & \multicolumn{8}{|c|}{ Sayısal analizlerden belirlenen en yüksek eksenel kuvvet $(\mathrm{kN} / \mathrm{m})$} \\
\hline & \multicolumn{8}{|c|}{ Dolgu yüksekliği H(m) } \\
\hline & \multicolumn{2}{|c|}{$2 \mathrm{~m}$} & \multicolumn{2}{|c|}{$4 \mathrm{~m}$} & \multicolumn{2}{|c|}{$6 \mathrm{~m}$} & \multicolumn{2}{|c|}{$8 \mathrm{~m}$} \\
\hline & Orta & İnce & Orta & İnce & Orta & İnce & Orta & İnce \\
\hline$\varnothing 600$ & 16.8 & 16.9 & 27.3 & 32.2 & 38.3 & 44.6 & 44.5 & 51.8 \\
\hline$\varnothing 800$ & 22.8 & 26.1 & 37.5 & 43.7 & 52.4 & 60.4 & 61.2 & 70.4 \\
\hline$\varnothing 1000$ & 29.4 & 32.9 & 47.9 & 55.2 & 66.9 & 76.4 & 73.9 & 89.1 \\
\hline$\varnothing 1200$ & 36.1 & 39.8 & 58.7 & 66.9 & 81.6 & 92.3 & 95.3 & 107.8 \\
\hline$\varnothing 1400$ & 43.5 & 47.05 & 69.6 & 78.7 & 95.9 & 108.1 & 112.5 & 126.6 \\
\hline$\varnothing 1600$ & 49.8 & 53.9 & 80.7 & 90.6 & 110.9 & 124.2 & 129.9 & 145.4 \\
\hline$\varnothing 1800$ & 56.6 & 61 & 91.9 & 102.4 & 126 & 140.2 & 147.3 & 164.1 \\
\hline$\varnothing 2000$ & 63.5 & 67.9 & 103.1 & 114.3 & 141 & 156.2 & 166.8 & 182.8 \\
\hline
\end{tabular}

Tablo 12 ve Tablo 13'te sayısal analizlerden hesaplanan kesit tesirleri kullanılarak boru tasarımı için gerekli donatı alanı ASCE 15-98'de belirtildiği gibi Eşitlik 9'dan hesaplanmıştır.

$$
A_{S} \geq \frac{\left.g \phi d-N u \sqrt{g\left[g(\phi d)^{2}-N u(2 \phi d-h)-2 M u\right.}\right]}{f y}
$$

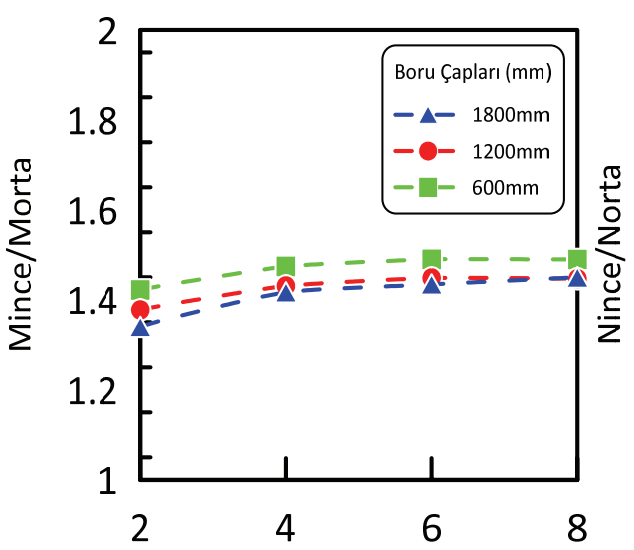

Dolgu Yükseklikleri (m)

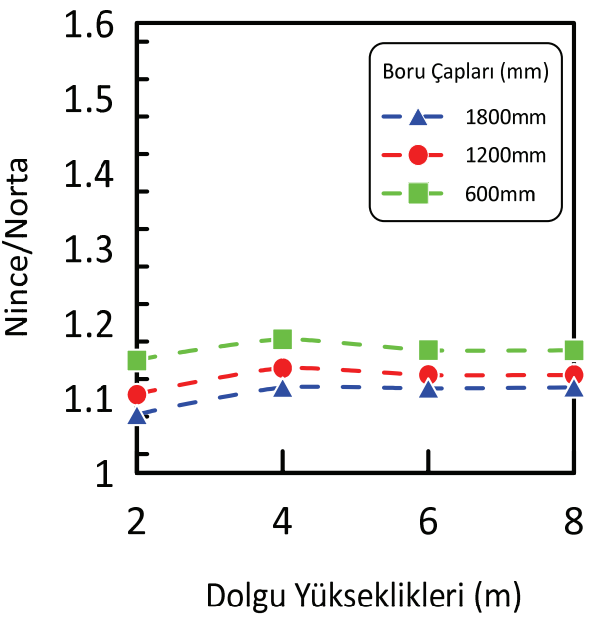

Şekil 8 - Sonlu elemanlar ă̆ sılkılı̆̆ının değişiminin kesit tesirlerine olan etkisi

Burada; $A_{\mathrm{s}}$ birim uzunluk için gerekli donatı alanı; $\mathrm{f}_{\mathrm{y}}$ donatı akma dayanımı; d paspayı; $\mathrm{h}$ boru et kalınlığı; $\mathrm{Mu}$; Tasarım momenti, Nu eksenel kuvvet; (basınç durumunda pozitif alınır); $\varnothing$ direnç faktörü; $g$ 0.85 x b x fc; b hesap genişliği; $f_{c}$ beton tasarım mukavemetini 
temsil etmektedir. Hesaplamalarda donatı akma dayanımı $\mathrm{f}_{\mathrm{y}} 485 \mathrm{MPa}$, beton tasarım mukavemeti $\mathrm{f}_{\mathrm{c}}$ ise $45 \mathrm{MPa}$ alınmıştır. Donatı alanı hesabı için boru çaplarına göre Eşitlik 9'da kullanılan parametreler Tablo 14'te verilmiştir. Eşitlik 9'dan hesaplanan donatı alanlarının boru çapı ve dolgu yüksekliğine göre değişimi Tablo 15 'te sunulmuştur. İnce sonlu elemanlar ağı dikkate alınarak hesaplanan bu sarmal donatı alanlarının boru çapı ile dolgu yüksekliğine bağlı değişimi Şekil 9'da bir abak halinde gösterilmiştir. Beklendiği gibi boru çapı ve dolgu yüksekliği arttıkça gerekli donatı alanı da artış göstermektedir. Böylece, Şekil 9'da gösterilen abaktan faydalanılarak, Tip 4 kurulum koşulları için beton boruları imalatında dikkate alınması gereken donatı alanları pratik olarak belirlenebilmektedir.

Tablo 14 - Donatı hesabında boru çaplarına göre kullanılan parametreler

\begin{tabular}{ccc}
\hline $\begin{array}{c}\text { Boru Çapı } \\
(\mathbf{m m})\end{array}$ & $\begin{array}{c}\text { h (Boru duvar kalınlığı) } \\
(\mathbf{m m})\end{array}$ & $\begin{array}{c}\text { d (Paspayı) } \\
(\mathbf{m m})\end{array}$ \\
\hline$\varnothing 600$ & 100 & 70 \\
\hline$\varnothing 800$ & 120 & 90 \\
\hline$\varnothing 1000$ & 120 & 90 \\
\hline$\varnothing 1200$ & 140 & 110 \\
\hline$\varnothing 1400$ & 140 & 110 \\
\hline$\varnothing 1600$ & 170 & 140 \\
\hline$\varnothing 1800$ & 200 & 170 \\
\hline$\varnothing 2000$ & 200 & 170 \\
\hline
\end{tabular}

Tablo 15 - Tip 4 Kurulum için hesaplanan sarmal donatı alanı

\begin{tabular}{|c|c|c|c|c|c|c|c|c|}
\hline \multirow{4}{*}{$\begin{array}{c}\text { Boru Çapı } \\
\text { (mm) }\end{array}$} & \multicolumn{8}{|c|}{ Sayısal analizlerden belirlenen kesit tesirlerine göre sarmal donatı alanı $\left(\mathrm{mm}^{2}\right)$} \\
\hline & \multicolumn{8}{|c|}{ Dolgu yüksekliği H(m) } \\
\hline & \multicolumn{2}{|c|}{$2 \mathrm{~m}$} & \multicolumn{2}{|c|}{$4 \mathrm{~m}$} & \multicolumn{2}{|c|}{$6 \mathrm{~m}$} & \multicolumn{2}{|c|}{$8 \mathrm{~m}$} \\
\hline & Orta & İnce & Orta & İnce & Orta & İnce & Orta & İnce \\
\hline$\varnothing 600$ & 53.4 & 65.1 & 80.7 & 106.5 & 111.1 & 146.2 & 128.1 & 168.5 \\
\hline$\varnothing 800$ & 72.4 & 93.5 & 112.9 & 148.7 & 155.4 & 204.7 & 180.2 & 236.3 \\
\hline$\varnothing 1000$ & 109.5 & 141.4 & 167.7 & 221.3 & 228.6 & 303.7 & 253.4 & 352.6 \\
\hline$\varnothing 1200$ & 133.8 & 170.9 & 201.1 & 264.7 & 273.8 & 361.8 & 320.1 & 422.6 \\
\hline$\varnothing 1400$ & 173.9 & 260.2 & 223.4 & 350.2 & 303.7 & 476.8 & 354.8 & 560.1 \\
\hline$\varnothing 1600$ & 193.8 & 295.9 & 282.4 & 447.7 & 382.7 & 505.1 & 447.4 & 593.2 \\
\hline$\varnothing 1800$ & 209.5 & 304.8 & 304.1 & 458.3 & 410.3 & 538.1 & 478.9 & 632.9 \\
\hline$\varnothing 2000$ & 253.7 & 317.5 & 365.5 & 478.5 & 491.7 & 647.2 & 596.8 & 762.9 \\
\hline
\end{tabular}




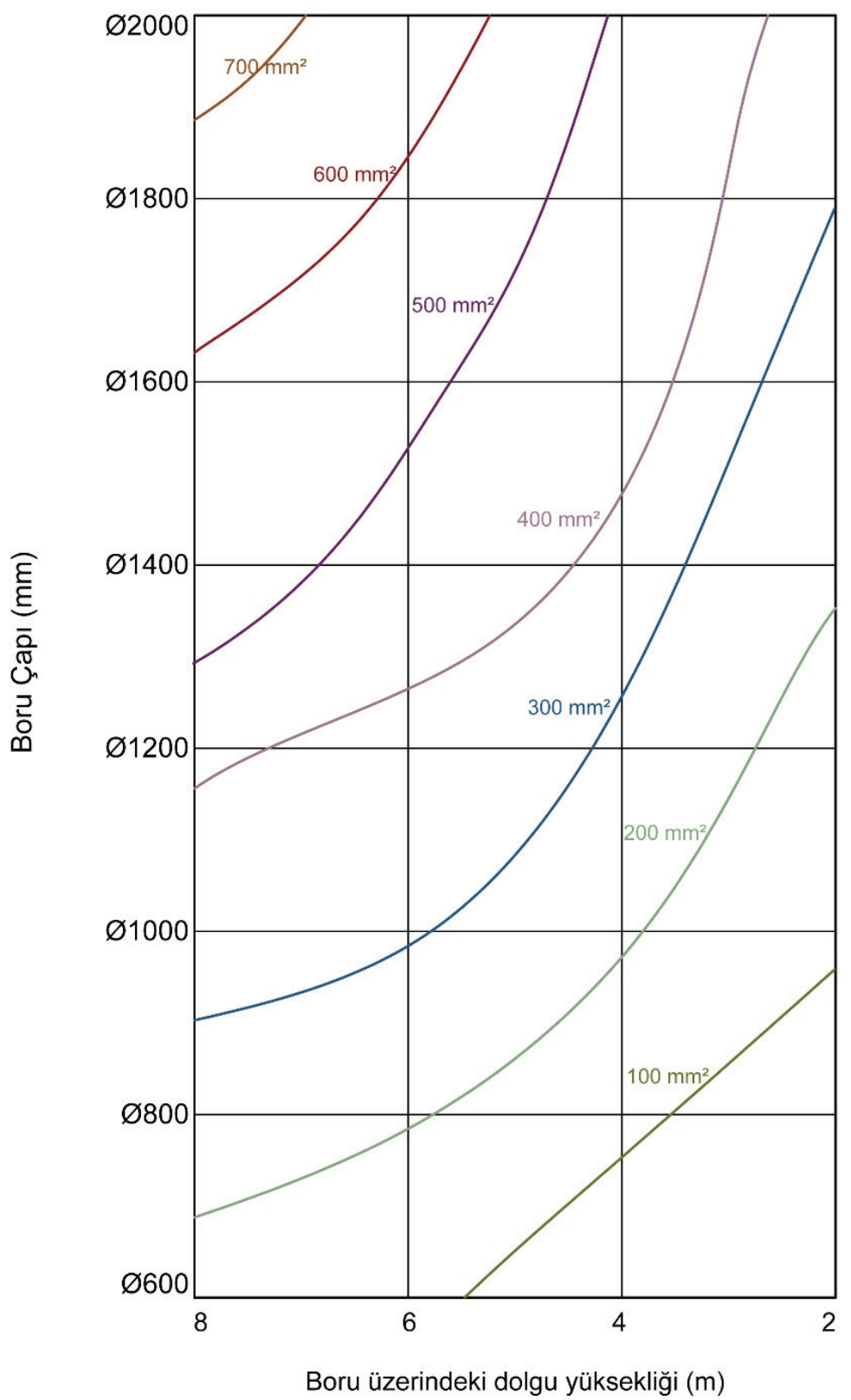

Şekil 9 - Boru çapı ve gömülme derinliğine bağlı olarak gerekli minimum sarmal donatı alanı abă̆ı (ince sonlu elemanlar ă̆ ile hesaplanan değerlerden) 


\subsection{Sayısal Analizlerden Belirlenen Donatı Alanlarının İller Bankası Donatı Alanları ile Karşılaştırılması}

Ülkemizde yaygın olarak gömülü beton boruların tasarımında İller Bankası A.Ş kriterleri dikkate alınmaktadır. Tablo 16'da İller Bankası A.Ş'nin güncel olarak kullandığı boru çaplarına karşılık gerekli donatı alanları gösterilmiştir. Bu donatı alanları 1m ile 8m arasında değişen dolgular altında kalan boruların en elverişsiz gömülme durumuna göre tüm geri dolgu malzemeleri için verilmiştir.

Tablo 16 - İller Bankası tarafindan kullanılan sarmal donatı alanları [18]

\begin{tabular}{cc}
\hline $\begin{array}{c}\text { Boru Çapı } \\
(\mathbf{m m})\end{array}$ & $\begin{array}{c}\text { Donatı Alanı } \\
\left(\mathbf{m m}^{\mathbf{2}} \mathbf{)}\right.\end{array}$ \\
\hline$\varnothing 600$ & 447.958 \\
$\varnothing 800$ & 519.526 \\
\hline$\varnothing 1000$ & 678.564 \\
\hline$\varnothing 1200$ & 1039.05 \\
\hline$\varnothing 1400$ & 1192.79 \\
\hline$\varnothing 1600$ & 1357.13 \\
\hline$\varnothing 1800$ & 1532.07 \\
\hline$\varnothing 2000$ & 1717.62 \\
\hline
\end{tabular}

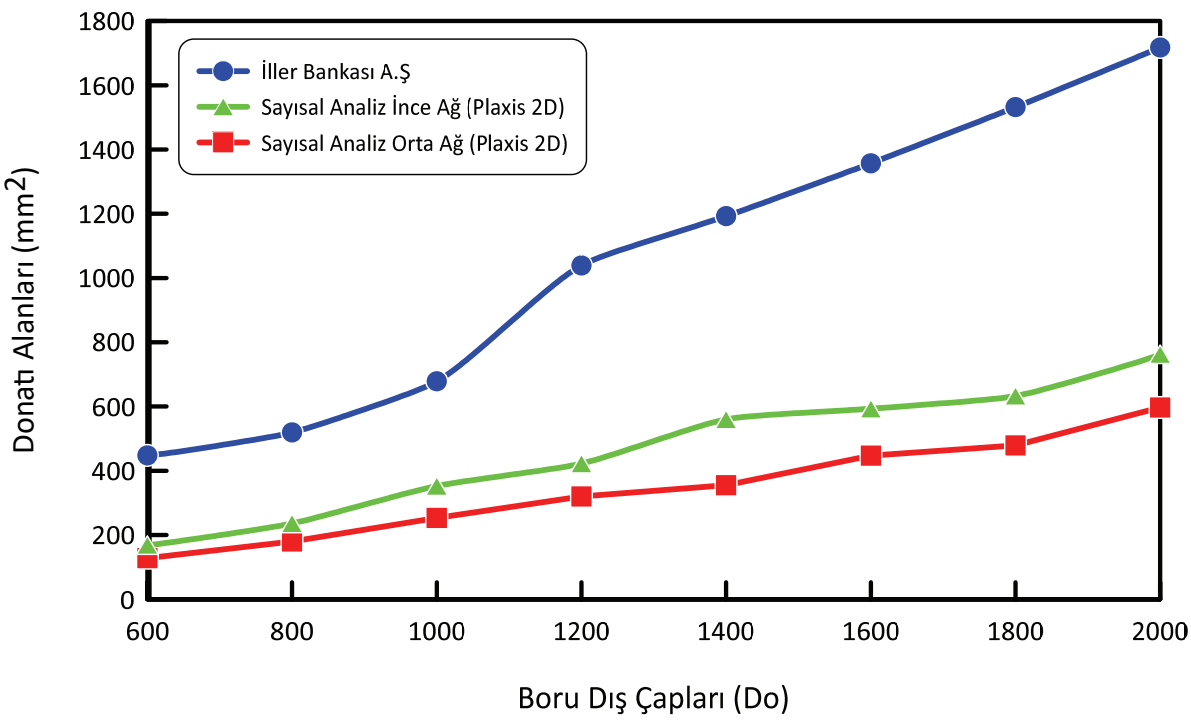

Şekil 10 - İler Bankası A.Ş tarafindan uygulanan ve sayısal analizlerden hesaplanan donatı alanlarının karşılaştırılması 
Şekil 10'da İller Bankası A.Ş ve yapılan sayısal analizlerden en elverişsiz tesir kuvvetleri dikkate alınarak hesaplanan donatı alanlarının karşılaştırılması gösterilmiştir. Görüldüğü gibi İller Bankası tarafindan kullanılan sarmal donatı alanları sayısal analiz sonuçlarına göre yaklaşık olarak 2.5-3 kat daha güvenli tarafta kalmaktadır. İller Bankası tarafından kullanılan donatı alanları Tablo 2'de belirtilen tüm gömülme koşulları için uygulanmaktadır. Tip 4 gömülme koşulları, beton borular için en olumsuz koşulları içermektedir. Bu çalışma kapsamında yapılan sayısal analizler ve karşılaştırmalar dikkate alındığında, ülkemizde oldukça güvenli yönde kalınarak betonarme boru tasarımı yapıldığı görülmektedir. Boru hatları kilometrelerce devam eden uzun alt yapı sistemleri olarak değişken zemin koşullarından geçmekte ve her zaman şartnamelerde belirtilen nitelikli dolgu malzemelerine ulaşmak mümkün olamamaktadır. Bu bakımdan, gömülü boru tasarımları yapılırken geçtiği güzergâhın zemin koşulları, boru özellikleri ve yükleme durumu dikkate alınarak zemin-boru etkileşimi ile davranışı incelenerek, şartnameler ile karşılaştırılmaları yapılmalıdır.

\section{SONUÇLAR VE ÖNERILER}

Doğrudan tasarım yöntemi (SIDD) Tip 4 boru kurulumunda, tabanda kayaç malzeme olmadığı koşullarda boru tabanında özel bir yatak tabakasına ihtiyaç yoktur. Bu çalışmada referans alınan Barrie sahasında yapılan arazi deneyinde, geri dolgu malzemesi olarak az miktarda ince dane içeren iyi derecelenmiş çakıllı kum kullanılmış ve temel zemininde kötü derecelenmiş siltli kum yer almaktadır. Beton boru tabandaki kötü derecelenmiş siltli kum üzerine oturtularak SIDD Tip 4 koşullarında kurulum gerçekleştirilmiştir. Bu makale kapsamında Barrie arazi deneyinin sayısal modeli Plaxis 2D (2019) kullanılarak oluşturulmuş ve arazide alınan gerilme ölçümleri ile hesap sonuçları karşılaştırılarak model doğrulandıktan sonra parametrik çalışma yapılmıştır. Parametrik çalışma kapsamında gömülme derinliğine karşıllk olarak artan dolgu yükü ile boru çapı değişimi dikkate alınarak tesir kuvvetlerindeki ve donatı alanındaki değiş̧imler belirlenmiştir. Ülkemizde gömülü boru tasarımında güncel olarak kullanılan İller Bankası A.Ş kriterlerine göre belirtilen donatı alanları için karşılaş̧ırması yapılmıştır. Yapılan bu çalışmaların sonuçlarına göre;

1. SIDD yönteminde Tip 4 kuruluma göre boru bölgelerindeki toplam iç kuvvetlerin hesaplanmasında Tablo 7'de görüldügüü gibi zemin yükü $\left(\mathrm{W}_{\mathrm{e}}\right)$ etkisi, taşı yüklerinden dolayı oluşan hareketli yüklere $\left(\mathrm{W}_{\mathrm{L}}\right)$ göre daha baskındır.

2. Zemin-boru etkileşimi dikkate alınarak sonlu eleman analiz yöntemi ile yapılan parametrik sayısal analizlerden elde edilen kesit tesirleri (Tablo 12 ve Tablo 13) sunulmuştur. Boru çapı ve dolgu yüksekliği artırıldığında boru kesitindeki eğilme momentleri ve eksenel kuvvetlerde beklenildiği gibi artış meydana gelmiştir. Sonlu elemanlar ağı sıkılığının ortadan inceye doğru artırılması boruda meydana gelen kesit tesirlerini etkilemiş ve ağ sıkılığının artmasına bağlı olarak moment değerlerinde Şekil 8'de görüldüğü gibi yaklaşı $\% 40$, eksenel kuvvet değerlerinde ise yaklaşı $\% 15$ oranında artış meydana gelmiştir.

3. Zemin-boru etkileşiminin dikkate alındığı sayısal analizler ve doğrudan tasarım yöntemine göre belirlenen eğilme momentleri karşılaş̧tırıldığında, SIDD ile hesaplanan eğilme momentlerinin sayısal analizlere göre belirlenen eğilme momenti değerlerinden 
daha büyük olduğu görülmüştür. Böylece SIDD yöntemine göre yapılan tasarımın zeminyapı etkileşimi dikkate alınan tasarımlara göre daha güvenli tarafta kaldığı söylenebilir.

4. Çalışma kapsamında SIDD yönteminde Tip 4 gömülme koşullarına göre zemin-yapı etkileşimi dikkate alınarak yapılan parametrik sayısal analizlerden Şekil 9'daki abak elde edilmiştir. Bu abak beton borunun üzerindeki dolgu yüksekliği ile boru çapına bağlı olarak gerekli donatı alanını vermektedir. Tasarımcıların pratik kullanımı için oluşturulmuştur.

5. Yapılan sayısal analizlerden elde edilen düşey gerilme dağılımları incelendiğinde, borunun taban bölgesinde gerilme konsantrasyonu meydana geldiği gözlemlenmiştir. $\mathrm{Bu}$ durumun, SIDD yönteminde kullanılan Heger zemin basıncı dağılımları ile paralellik taşıdığı görülmüştür.

6. Parametrik sayısal analizlerde orta ve ince ağ kullanılarak hesaplanan donatı alanları ile İler Bankası A.Ş'nin gömülü betonarme boru tasarımı için kullandığı donatı alanları karşılaştırılmıştır. Şekil 10'dan da görüldüğü gibi boru çaplarına karşılık gelen gerekli donatı alanlarında orta ağ kullanıldığında 3, ince ağ kullanıldığında 2-2.5 kat fark vardır. Eşitlik 9 'da görüldüğü gibi bu donatı alanlarının hesaplanmasında iç kuvvetlerin büyük etkisi olduğu gibi kullanılan donatı ve beton malzeme dayanımlarının da etkisi olduğu unutulmamalıdır. Bu durum, İller Bankası A.Ş’nin gömülü betonarme borular için gerekli donatı alanlarında oldukça güvenli tarafta kaldığını göstermektedir. Böylece, ülkemizde yapılan betonarme boru tasarımlarının ekonomik olmadığı söylenebilir.

\section{Semboller}

$\begin{array}{ll}\text { W } & \text { : Toplam yük } \\ \mathrm{D}_{\mathrm{i}} & \text { : Boru iç çapı } \\ \mathrm{D}_{\mathrm{o}} & \text { : Boru dış çapı } \\ \mathrm{VAF} & \text { : Düşey kemerlenme faktörü } \\ \mathrm{HAF} & \text { : Yatay kemerlenme faktörü } \\ \mathrm{W}_{\mathrm{e}} & \text { : Boru üzerindeki zemin yükü } \\ \mathrm{W}_{\mathrm{p}} & \text { : Borunun kendi ağırlığından dolayı oluşan yük } \\ \mathrm{W}_{\mathrm{f}} & \text { : Akışkan yükü } \\ \mathrm{W}_{\mathrm{L}} & \text { : Hareketli yük } \\ \mathrm{d} & \text { : Paspayı } \\ \mathrm{PL} & \text { : Prizma yükü } \\ \mathrm{H} & \text { : Dolgu yüksekliği } \\ \text { w } & \text { : Zemin birim hacim ağırlığı } \\ \text { As } & \text { : Birim uzunluk için gerekli eğilme donatısı alanı } \\ \mathrm{g} & \text { : 0.85bf' } \\ \text { b } & \text { : Birim genişlik } \\ \mathrm{h} & \text { : Duvar kalınlığı }\end{array}$


$\mathrm{f}_{\mathrm{c}}^{\prime} \quad$ : Beton malzeme dayanımı

$\mathrm{f}_{\mathrm{y}} \quad$ : Donatı malzeme dayanımı

$\Phi \quad$ : Direnç faktörü

$\mathrm{M}_{\mathrm{u}} \quad$ : Birim genişliğe etkiyen tasarım momenti

$\mathrm{N}_{\mathrm{u}} \quad$ : Birim genişliğe etkiyen tasarım eksenel kuvveti

EI : Eğilme Rijitliği

EA : Eksenel Rijitlik

$\gamma \quad$ : Birim hacim ağırlık

HS : Pekleşen zemin modeli

$\mathrm{E}_{\mathrm{c}} \quad$ : Elastisite modülü

$\gamma_{\mathrm{c}} \quad$ : Beton malzeme yoğunluğu

$\mathrm{E}_{50}{ }^{\text {ref }} \quad$ : Referans elastisite modülü

$\mathrm{E}_{\text {oed }}{ }^{\text {ref }} \quad$ : Referans ödometre modülü

$\mathrm{E}_{\mathrm{ur}}^{\text {ref }} \quad$ : Referans yükleme boşaltma modülü

$\mathrm{m} \quad$ : Üstel malzeme sabiti

$\mathrm{c}^{\text {'ref }} \quad$ Kohezyon

$\mathrm{C}_{\mathrm{mi}} \quad$ : Moment hesabı için boru analiz katsayısı

$\mathrm{C}_{\mathrm{ni}} \quad$ : Eksenel kuvvet hesabı için boru analiz katsayısı

$\mathrm{C}_{\mathrm{vi}} \quad$ : Kesme kuvveti hesabı için boru analiz katsayısı

$\mathrm{W}_{\mathrm{i}} \quad$ : Boru üzerine gelecek yüklerin toplamı

$\mathrm{D}_{\mathrm{m}} \quad$ : Boru ortalama çap1

$\phi_{\mathrm{u}} \quad$ : İçsel sürtünme açısı

$v_{\mathrm{ur}} \quad$ : Poisson oranı

$\mathrm{p}^{\text {ref }} \quad:$ Referans gerilme

$\mathrm{R}_{\mathrm{f}} \quad$ : Göçme oranı

A1-A6 : Toprak basıncının boyutsuz düşey ve yatay bileşenleri

$\mathrm{a}-\mathrm{v} \quad$ : Düşey ve yatay gerilmeleri elde etmek için boyutsuz katsayılar

\section{Kaynakça}

[1] Marston, A., Anderson, A. C, "The Theory of Loads on Pipes in Ditches and Tests on Cement and Clay Drain Tile and Sewer Pipe”, Bulletin 31, Iowa Engineering Experimental Station, Ames, Iowa, 1913.

[2] Janssen, H.A, 'Versuche über Getreidedruck in Silozellen. Zeitschrift des Vereinesdeutscher Ingenieurs', 1895. 
[3] Sargand, S.M, Hazen, G.A., Vaithianathan, E, and Hurd, J.O, 'Performance verification of a concrete pipe,', Concrete International, July, pp. 23-27, 1995.

[4] Spangler, M.G, 'The Supporting Strength of Rigid Pipe Culverts", Bulletin 112, Iowa State College, 1933.

[5] Marston, A.' The Theory of External Loads on Closed Conduits in the Light of the Latest Experiments', Paper presented at the Proceedings of the Highway Research Board 30, Washington, D.C, 1930.

[6] Canadian Standards Association (CSA), "Design of concrete structures', CSA A23. 3-04. CSA, Rexdale, Ontario, 2004.

[7] Kılıç, H., Akınay E., ' Gömülü HDPE Borularda Esneme Davranışının İncelenmesi ', Teknik Dergi, 2019 9373-9398, Yazı 548, 2019.

[8] Rajah, S., McCabe, M., Plattsmier, J. 'Classification and Specification of Bedding and Backfill for Buried Pipelines', Pipelines Conference, Miami Beach, Florida, 2012.

[9] Erdogmus, E., Tadros, M, ' Behavior and Design of Buried Concrete Pipes Phase II ', Nebraska Department of Roads Research Reports, 75, 2009.

[10] Allard, E., Naggar, E., 'Pressure Distribution around Rigid Culverts Considering Soil-Structure Interaction Effects ', Int. J. Geomech., ASCE, 2016.

[11] ACPA, "Concrete Pipe Technology Handbook", American Concrete Pipe Association, 1993.

[12] ASCE 15-98, ' Standard practice for direct design of buried precast concrete pipe using standard installation (SIDD)', 2000.

[13] ACPA, "'Concrete Pipe Design Manual ", American Concrete Pipe Association, 2011.

[14] Wong, L., Allouche, E., Dhar, A., Baumert, M., ve Moore, I., ''Long Term Monitoring of SIDD Type IV Installations ’ Can. Geotech. J., 43(4), 392-408, 2006.

[15] ACPA, 'Design Data 5. Multiple Pipe Installations: Trench Condition.', American Concrete Pipe Association, 2011.

[16] ASTM, 'Standard test method for laboratory determination of water (moisture) content of soil and rock by mass (D-2216-98).", Annual book of ASTM standards, American Society for Testing and Materials (ASTM), West Conshohocken, Pa., 1998.

[17] ASTM, 'Standard test methods for laboratory compactions of characteristics of soil using standard effort (D-698-00).", Annual book of ASTM standards, American Society for Testing and Materials (ASTM), West Conshohocken, Pa., 2000.

[18] İller Bankası A.Ş., "Beton boru çaplarına göre sarmal donatı alanları,', İller Bankası A.Ş, Ankara, Temmuz 2015. 